\title{
Study of Adenosine Deaminase Activity As A Biochemical Marker of Cell Mediated Immunity in Tuberculous Meningitis, Tuberculous Pleural Effusion and Tuberculous Ascites
}

\author{
SHASHIKANT AGARWAL ${ }^{1}$
}

\begin{abstract}
:
The present study conducted with the aim that ADA estimation is a simple cheaper and quicker biochemical test and could provide additional supportive evidence for the diagnosis of tuberculous meningitis, tuberculous pleural effusion, tuberculous ascites in clinically suspected cases and will therefore help in early institution of therapy to these patients. The data was collected and interpreted at department of Physiology and Department of Medicine Gandhi Medical College, Bhopal.
\end{abstract}

Keyword: ADA, Tubeculous, Biochemical test, Diagnosis

\section{Introduction:}

Tuberculosis meningitis remains an important cause of morbidity and mortality in India. Due to lack of early and timely diagnosis of tuberculosis meningitis, the fatality rate remains high, even when it is not fatal, the sequel is distressing and disabling. Thus, early and correct treatment is essential for a successful outcome in patients of tuberculosis meningitis.

Among the extra pulmonary presentations, pleural TB is second in frequency after tuberculosis lymphadenitis. Conventional methods for the diagnosis of pleural TB have proven inefficient. Direct examination of pleural fluid and Ziehl- Neelsen staining requires bacillus concentrations of $10000 / \mathrm{ml}$ and, therefore, has a low sensitivity. Although a culture is more sensitive it requires 2 to 6 weeks to sensitivity of pleural biopsy specimens is reportedly higher whether by culture or histological evaluation. However this procedure requires greater expertise, is more invasive, and is subject to sampling error. The paucity of bacilli and the nonspecific cytochemical characteristic of pleural fluid in pleural B mandate more invasive procedures such as pleural biopsy for differential diagnosis. Although tuberculosis pleural effusion may resolve over a period of several months without treatment, a failure to diagnose and treat pleural TB can result in progressive disease and the involvement of other organs.

Piras et al. consider ADA as a Marker of cell mediated immunity, with an increase in its serum level in different diseases. Regarding its main physiologic activity, ADA is related to lymphocytic differentiation and proliferation, showing a significant increase in its values during the mythogenic and antigenic response of lymphocyte. ${ }^{1,2}$

ADA plays a part in the differentiation of lymphid cells and the maturation of monocytes to macrophages. The congential and genetically determined deficit of this enzyme with its autosomal receive trait. It is reported to be associated with severe form of combined immuno deficiency and its responsible for an increase in toxic nucleotides that prevent the differentiation or proliferation (or both) of $\mathrm{T}$ lymphocytes and thus a normal immune function mediated by cells. The raising of the levels of ADA activity under antigenic stimulation shows the importance of this enzyme in the rapid proliferation of cells in order to prevent the accumulation of toxic metabolistis. Therefore, an increased ADA activity is present in several circumstances in pleural, pericardiac and peritoneal effusion of a tuberculous nature and in tuberculous cerebrospinal fluid, where ADA values are significantly higher than in normal group ad in other neurological disease.

Tuberculosis occurs worldwide and is rampant in many countries. Increased level of ADA is found in various forms of tuberculosis making it a marker for the same. Hence in the present study, ADA activity was studied for easy diagnosis of tuberculous meningitis, tuberculous pleural effusion and tuberculous ascites. The present work was done in the department of Physiology and Department of Medicine Gandhi Medical College, Bhopal. The biochemical investigations were carried out in the department of Biochemistry of the institutions.

1. Assistant Professor, Department of Physiology, Jhalawar Medical College

Correspondence: Dr. Shashikant Agarwal, Assistant Professor, Department of Physiology, Jhalawar Medical College ; E Mail inbiosci@gmail.com 


\section{Materials and methods:}

The study comprised of 30 cases of tuberculous meningitis, 30 cases of tuberculous pleural effusion and 30 cases of tuberculous ascites who volunteered for the study. The study population consisted of 45 men 45 women with an average age range of 14-70 years.

\section{Diagnostic Criteria of Tuberculous Meningitis:}

Physical Examination - Cobweb formation, clear fluid

\section{Biochemical examination of CSF -}

$\varnothing$ Raised protein $100-200 \mathrm{mg} / \mathrm{dL}$.

$\varnothing$ Low glucose $<40 \%$ of corresponding blood sugar.

$\varnothing$ Raised cell count predominantly lymphocytes $100-500$ cells / cumm.

$\varnothing \quad$ ADA level $>10 \mathrm{U} / \mathrm{L}$.

Diagnostic Criteria For Tuberculous Pleural Effusion:

Physical examination - Clear serous yellow -

Biochemical Examination of Pleural Fluid

$\varnothing$ Raised protein $>50 \%$ serum proteins.

$\varnothing$ Glucose $<60 \mathrm{mg} / \mathrm{dL}$.

$\varnothing$ Cell count $>500$ cumm predominant mononuclear cells.

$\varnothing \quad \mathrm{ADA}>40 \mathrm{U} / \mathrm{L}$.

Diagnostic Criteria For Tuberculous Ascites:

Physical - Examination - Yellow, Clear

Biochemical examination of ascitic fluid :

$\varnothing$ Raised protein $>2.5 \mathrm{~g} / \mathrm{dL}$.

$\varnothing$ Glucose $<60 \mathrm{mg} / \mathrm{dL}$

$\varnothing$ Cell count 150 - 4000 cell / cumm (lymphocyte predominant).

$\varnothing \quad$ ADA level $>40 \mathrm{U} / \mathrm{L}$.

- Clinical Examination - Detailed clinical examination was done to exclude the cases suffering from diseases other than tuberculous etiology impairing the cellular immunity. Clinical examination was done to assess cardiorespiratory status and general condition of study population.

- Assessment of nutritional status: Anthropometric measurements were done and Body mass index was calculated as per the standard procedure.

- Hematological Examination: Estimation of Leucocyte count, hemoglobin and ESR was done by employing standard methods.

- Biochemical Investigation: It includes, estimation of glucose in serum, by GOD POD kit method, estimation of Protein by Biuret Kit method, estimation of ADA by ADA-MTB kit method. (Guiesti, G, Galanti B., 1986), estimation of Blood urea by urease GLDH Method (Kinetic UV Test) and estimation of Serum Creatinine by Jaffe's reaction without deproteinization, kinetic method.

- Statistical Analysis: For the data analysis the mean and standard deviation were calculated. The statistical significance was calculated using paired ' $t$ ' test. Correlation coefficient ' $r$ ' was calculated to establish association between the variables.

\section{Results and observations:}

The study comprised of 30 normal healthy control aged 1848 years and newly diagnosed 30 cases of tuberculous meningitis, 30 cases of tuberculous pleural effusion, 30 cases of tuberculous ascites who volunteered for the study. The study population consisted of 45 men and 45 women with an average age range of 14-70 years. The adenosine deaminase was measured and correlated with various parameters.

Table-I depicted, the low mean hemoglobin levels in all the three groups reflect the poor nutritional status of the patients under study. On the other hand the mean ESR values recorded were on higher side supporting the tuberculous pathology. Total leucocyte count was in the normal range in all the three groups.

Table-I

Hematological Profile of The Study Population

\begin{tabular}{|c|c|c|c|c|}
\hline S. No. & Parameters & $\begin{array}{l}\text { Tuberculous meningitis } \\
(\mathrm{n}=30)\end{array}$ & $\begin{array}{l}\text { Tuberculous ascites } \\
(\mathrm{n}=30)\end{array}$ & $\begin{array}{l}\text { Tuberculous Pleural Effusion } \\
(\mathrm{n}=30)\end{array}$ \\
\hline \multirow[t]{3}{*}{1} & $\mathrm{Hb}(\mathrm{gm} / \mathrm{dL})$ & & & \\
\hline & Mean + S.D. & $11.03+1.97$ & $10.37+1.44$ & $11.13+2.02$ \\
\hline & Range & 7.-14.8 & $8.2-12.7$ & $8.3-15.3$ \\
\hline \multirow[t]{3}{*}{2} & ESR (at the e & r in mm) & & \\
\hline & Mean + S.D. & $25.8+13.59$ & $26.66+11.54$ & $22.97+8.14$ \\
\hline & Range & $9-70$ & 15.71 & $5-41$ \\
\hline \multirow[t]{3}{*}{3} & TLC/ cumm & & & \\
\hline & Mean + SD & $6953.3+720.98$ & $7359+2195.5$ & $7661.7+1427.2$ \\
\hline & Range & $5400-8400$ & $1050-12200$ & $5200-10600$ \\
\hline
\end{tabular}

$\mathrm{Hb} \quad-$ Hemoglobin

ESR - Erythrocyte sedimentation rate

TLC - Total leucocyte count 
Data in Table-II depicted that statistical analysis revealed a significant difference in CSF ADA levels, protein and CSF leucocyte count between group I (cut off value $<10 \mathrm{U} / \mathrm{L}$ ) and group II (cut Off value $>10 \mathrm{U} / \mathrm{L}$ ). The mean values of CSF glucose differed appreciably in the two groups but statistical significant difference was not obtained. The mean CSF glucose remained $<40 \mathrm{mg} / \mathrm{dL}$ in the group II.

The observation in table-III, revealed statistical significant positive correlation of ADA activity with CSF protein and lymphocyte count whereas highly significant negative correlation could be established between CSF ADA level and CSF glucose concentration.
The diagnosis of tuberculous pleural effusion was established by correlating the clinical findings with pleural fluid changes in relation to physical, biochemical and cytological examination. Table-IV showed the results of comparison of biochemical and leucocytes count based on ADA levels in tuberculous pleural effusion patients. Analysis of pleural fluid ADA level and leucocyte count in group I and group II showed statistically significant difference in the mean value $(p<0.01)$ although mean values of the pleural fluid protein in group II were on higher side as compared to group I and glucose level was also appreciably low ( $<60 \mathrm{mg}$ / dL).

Table-II

Comparison of biochemical and leucocyte count based on ada levels in tuberculous meningitis patients

\begin{tabular}{lllll}
\hline & \multicolumn{4}{c}{ Mean + SD } \\
\cline { 2 - 5 } & ADA U/L & $\begin{array}{l}\text { Protein } \\
(\mathrm{mg} / \mathrm{dL})\end{array}$ & $\begin{array}{l}\text { Glucose } \\
(\mathrm{mg} / \mathrm{dL})\end{array}$ & $\begin{array}{l}\text { Leucocyte Count } \\
(\text { per cumm })\end{array}$ \\
\hline CSF ADA $<10$ U/L I $(\mathrm{n}=9)$ & $5.22+2.16$ & $51.33+56.24$ & $57.33+17.42$ & $24.88+44.88$ \\
CSF ADA $>10 \mathrm{U} / \mathrm{L}$ II $(\mathrm{n}=21)$ & $37.75+18.03$ & $228.41+159.56$ & $35.59+10.97$ & $164.86+75.43$ \\
\hline 't' value I Vs II & 8.75 & 2.19 & 0.10 & 6.84 \\
' $\mathrm{p}$ ' value & 0.001 & 0.05 & $\mathrm{NS}$ & 0.001 \\
\hline
\end{tabular}

Table-III

Correlation Of CSF ADA Activity With Parameters Measured In Tuberculous Meningitis

\begin{tabular}{llll}
\hline ADA (U/L)Mean + S.D. & Protein $(\mathrm{mg} / \mathrm{dL})$ & Glucose $(\mathrm{mg} / \mathrm{dL})$ & Lymphocyte $\%$ \\
& Mean + S.D. & Mean + S.D. & Mean + S.D. \\
I & II & III & IV \\
\hline $27.99+21.34$ & $175.29+158.88$ & $42.11+16.41$ & $88.4+16.10$ \\
Correlation coefficient (r) & I Vs II0.45 & I Vs III-0.58 & IVs IV0.37 \\
\hline 'P' value & 0.01 & .001 & 0.05 \\
\hline
\end{tabular}

Table-IV

Comparison of biochemical and leucocyte count based on ada levels in tuberculous pleural effusion patients

\begin{tabular}{|c|c|c|c|c|}
\hline & \multicolumn{4}{|c|}{ Mean + SD } \\
\hline & ADAU/L & $\begin{array}{l}\text { Protein } \\
(\mathrm{g} / \mathrm{dL})\end{array}$ & $\begin{array}{l}\text { Glucose } \\
(\mathrm{mg} / \mathrm{dL})\end{array}$ & $\begin{array}{l}\text { Leucocyte Count } \\
\text { (per cumm) }\end{array}$ \\
\hline Pleural fluid ADA $<40 \mathrm{U} / \mathrm{L} \mathrm{I}(\mathrm{n}=6)$ & $13.46+4.60$ & $2.91+1.44$ & $86.33+29.32$ & $302.33+314.47$ \\
\hline Pleural fluid ADA $>40 \mathrm{U} / \mathrm{L} \mathrm{II}(\mathrm{n}=24)$ & $90.78+27.89$ & $4.75+1.08$ & $47.49+1.08$ & $830.33+390.27$ \\
\hline 't' value I Vs II & 2.60 & 1.64 & 0.004 & 3.05 \\
\hline 'p' value & 0.01 & 0.10 & NS & 0.01 \\
\hline
\end{tabular}


Table-V, depicted the statistically significant $(\mathrm{p}<0.001)$ positive correlation between the pleural fluid ADA, protein and lymphocyte percentage. A negative correlation could be established between the pleural fluid ADA and glucose values. The observations were in conformity with the diagnostic criteria laid down.

In table-VI, Ascitic fluid ADA levels showed significant difference in group I and group II categorized on the basis of cut off values taken. The other three parameters i.e. ascitic fluid proteins, glucose and leucocyte count differed markedly as evident from the mean values but statistically the difference was found to be non significant.

An attempt has been made to correlate the ADA activity with the biochemical and cytological parameters measured (Table-VII). The ADA activity correlated well $(\mathrm{p}<0.001)$ with the ascitic fluid protein content and the lymphocyte count.
A statistically negative association was found between ADA activity and glucose content.

Table-VIII, showed the validity of AdA test as a diagnostic tool. In the present study using ADA cut off value of $10 \mathrm{U} /$ $\mathrm{L}$ in CSF for the diagnosis of tuberculous meningitis infection a sensitivity of nearly $100 \%$ and specificity $87.5 \%$ was demonstrated in clinically diagnosed tuberculous meningitis patients. False positive results were noted in $12.5 \%$ cases. High sensitivity and positive predictive value proved the reliability and usefulness of ADA estimation in TBM cases cut of the value of $40 \mathrm{U} / \mathrm{L}$. Similarly high sensitivity, specificity at cut off value of $40 \mathrm{U} / \mathrm{L}$ and low percentage of false negative cases in tuberculous pleural effusion and tuberculous ascites support the diagnostic usefulness of ADA test for early diagnosis of these conditions.

Table-V

Correlation of pleural fluid ada activity with parameters measured in tuberculous pleural effusion patients

\begin{tabular}{lccc}
\hline ADA (U/L) & $\begin{array}{c}\text { Protein (g/dL) } \\
\text { Mean+ S.D. }\end{array}$ & Glucose (mg/dL) & Lymphocyte \% \\
Mean + S.D. & Mean + S.D. \\
\hline I & II & III & IV \\
$75.32+40.12$ & $4.38+1.36$ & $55.26+23.74$ & $80.26+27.81$ \\
\hline Correlation coefficient (r) & IVs II0.60 & I Vs III- 0.65 & IVs IV0.64 \\
'p' value & $<0.001$ & $<0.001$ & $<0.001$ \\
\hline
\end{tabular}

Table-VI

Comparison Of Biochemical And Leucocyte Count Based On Ada Levels In Tuberculous Ascites Patients

\begin{tabular}{lcccc}
\hline & ADA U/L & $\begin{array}{c}\text { Mrotein } \\
(\mathrm{g} / \mathrm{dL})\end{array}$ & $\begin{array}{c}\text { Glucose } \\
(\mathrm{mg} / \mathrm{dL})\end{array}$ & $\begin{array}{c}\text { Leucocyte Count } \\
\text { (per cumm) }\end{array}$ \\
\hline Ascitic fluid ADA <40 U/L I $(\mathrm{n}=5)$ & $16.96+5.31$ & $1.92+0.60$ & $81.26+24.35$ & $233.2+261.63$ \\
Ascitic fluid ADA $>40 \mathrm{U} / \mathrm{L}$ II $(\mathrm{n}=25)$ & $88.66+28.08$ & $3.662+1.04$ & $46.89+10.63$ & $769.92+292.41$ \\
\hline ' $\mathrm{t}$ ' value I Vs II & 3.059 & 1.02 & 0.0004 & 1.67 \\
'p' value & 0.01 & $\mathrm{NS}$ & $\mathrm{NS}$ & 0.10 \\
\hline
\end{tabular}

Table-VII

Correlation Of Ascitic Fluid Ada Activity With Parameters Measured In Tuberculous Ascites Patients

\begin{tabular}{lccc}
\hline ADA (U/L) & Protein (g/dL) & Glucose (mg/dL) & \multicolumn{2}{c}{ Lymphocyte \% } \\
Mean + S.D. & Mean + S.D. & Mean + S.D. & Mean + S.D. \\
I & II & III & $77.9+23.10$ \\
\hline $76.71+37.35$ & $3.37+1.17$ & $52.62+18.57$ & IVs III0.48 \\
Correlation coefficient(r) & I Vs II0.56 & I Vs II-0.54 & $<0.001$ \\
\hline 'P' value & $<0.001$ & $<0.001$ & I \\
\hline
\end{tabular}


Table-VIII

Validity of ADA Test As A Diagnostic Tool

\begin{tabular}{lcccccc}
\hline Group & \multicolumn{7}{c}{ Parameters } \\
\cline { 2 - 7 } & $\begin{array}{c}\text { Sensitivity } \\
\%\end{array}$ & $\begin{array}{c}\text { Specificity } \\
\%\end{array}$ & $\begin{array}{c}\text { PPV } \\
\%\end{array}$ & $\begin{array}{c}\text { NPV } \\
\%\end{array}$ & $\begin{array}{c}\text { Percentage of } \\
\text { False Negative }\end{array}$ & $\begin{array}{c}\text { Percentage of } \\
\text { False Positive }\end{array}$ \\
\hline Tuberculous Meningitis & 99.90 & 87.5 & 95.23 & 77.77 & 9.09 & 12.5 \\
Tuberculous Pleural Effusion & 92 & 80 & 95.8 & 66.66 & 8 & 20 \\
Tuberculous Ascites & 96 & 80 & 96 & 80 & 4 & 20 \\
\hline
\end{tabular}

\section{Discussion:}

Tuberculosis has emerged as one of the most lethal disease men has faced. Inspite of presence of effective chemotherapy epidemiological data showed worldwide rise in incidence specially since AIDS incidence rose steeply. There is considerable urgency in establishing the correct diagnosis in patients with tuberculosis meningitis, tuberculous pleural effusion and tuberculous ascites because specific therapy is most effective when instituted early in the course of illness. The body fluids like CSF, pleural fluid and peritoneal fluid contain sensitive biochemical markers, these includes ADA, INF- $\alpha$ TNF- $\alpha$ and IL-1. The determination of ADA activity in these body fluids has been reported to be a valuable adjunct in the diagnosis of extra pulmonary tuberculosis. Since the value of ADA activity is mainly related to cellular immunity, in immuno-compromised patients. ADA activity reported was low as compared to immunocopetent hosts.

In the present study specimens from 90 patients were examined for ADA activity including tuberculous meningitis (30 CSF), tuberculous pleural effusion (30 pleural fluid), Tuberculous ascites (ascitic fluid 30 ) and 30 serum sample from control group. The probable diagnosis in all cases of TB was assigned according to clinical presentation which suggestive signs and symptoms, radiological, bacteriological and cytological criteria in all cases standard diagnostic procedure were followed.

Study group I : Tuberculous meningitis

\section{CSF Biochemistry and Cytology :}

On physical examination 93\% CSF sample appeared clear only $70 \%$ were found hazy. Cobweb appearance was found in only one sample.

\section{CSF Cytology :}

There is no general agreement on nomenclature for cytologic elements in normal CSF, Sheth identified lymphocytes, piaarchnoid mesothelial (PAM) cell, monocytes, and neutrophils as normally present, Kolmel identified lymphocytes monocytes, monocytoid" cells, neutrophils and ependymal cells normally present in CSF. ${ }^{3,4}$ There has been considerable controversy on whether neutrophils are present in "normal" CSF. Some authors consider even one neutrophil as abnormal (Cole) while others suggested that up to 10 percent neutrophils (e.g. 5 out of 50 cells counted) are within Normal limits (Sheth). ${ }^{3,4,5}$ According to Kolmel, neutrophils in CSF probably come from contamination by peripheral blood owing to traumatic tap. A neutrophilic reaction classically suggest, meningitis owing to pyogenic organisms. Increased numbers of lymphocytes have been reported in infections, including (1) viral maningoencephalitis (plasma cells, and some macrophages also may be present, (2) tuberculous meningitis.

\section{CSF Biochemistry :}

In the present study mean CSF protein measured was $175.29+158.88$ similar observations were reported by Kennedy et al. ${ }^{6}$

Fishman suggested that increased permeability of the blood CSF barrier is a common cause for pathologic increases in CSF proteins. In meningitis there is damage to the blood CSF barrier, plus decreased removal of protein molecules at the arachnoid villi. ${ }^{7}$

The glucose content of the CSF samples collected were analyzed the mean value obtained was $42.11+16.41 \mathrm{mg} / \mathrm{dL}$. CSF glucose levels in patients with TBM reported in various research publications are abnormal being $<40 \%$ of the corresponding blood sugar level. Decreased CSF glucose is considered present when CSF glucose is $<40 \mathrm{mg} / \mathrm{dL}$ in a fasting patient with normal plasma glucose in the present series in $73 \%$, CSF samples glucose level was $<40 \mathrm{mg} / \mathrm{dL}$ and I remaining $27 \%$ of cases CSF glucose level measured were $>40 \mathrm{mg} / \mathrm{dL}$. Kennedy et al. reported CSF glucose levels between $30-45 \mathrm{mg} / \mathrm{dL}$ in $48 \%$ cases and $>45 \mathrm{mg} / \mathrm{dL}$ in $17 \%$ cases out of 52 cases of TBM studied. Decreased CSF glucose may be due to impairment of active transport to increased utilization of glucose by CNS tissue. Swartz et al. reported decreased CSF glucose in patients with bacterial meningitis. ${ }^{8}$ 
In normal CSF samples ADA level $<10 \mathrm{U} / \mathrm{L}$ is considered normal. The CSF ADA activity measured in the present series was found to be considerably increased than normal $(27.9+21.34$, range $2.76 \mathrm{u} / \mathrm{L})$ in majority of the cases studied.

Results of present study seem to confirm the usefulness of ADA test for timely and early diagnosis of tuberculous meningitis. An attempt was made to study the association between CSF U/L leucocyte count and ADA activity. Increased ADA activity $(41.22+23.09)$ was found to correspond with increased leucocyte count (>200/cumm).

Similarly CSF ADA levels were related to CSF protein. The observation revealed that CSF samples having protein content $<100 \mathrm{mg} / \mathrm{dL}$ had mean ADA level 5.87+4.12 U/L. Samples containing protein content between 100-200 mg/ $\mathrm{dL}$ : had ADA level 28.62+15.84 U/L. On the other hand samples having $>200 \mathrm{mg} / \mathrm{dL}$ protein had ADA level 46.74+19.34 U/L. An attempt was made to correlate ADA level and protein concentration. A statistically significant $(\mathrm{P}<0.01)$ was obtained. Similar findings were reported by Malan et al.; $(\mathrm{r}=0.94, \mathrm{p}<0.001) .{ }^{9} \mathrm{ADA}$ activity is much higher in blood than in CSF Piras. et al. and Galanti studied lymphocyte ADA activity in tuberculous meningitis typhoid fever respectively. ${ }^{10,11}$ They concluded that ADA does not cross normal blood brain barrier. The related increased in the levels of ADA and protein in CSF in TBM may thus have their original least in part in damage to the blood brain barrier permitting ADA to enter the CSF from either the blood or adjacent cerebral tissue, alternatively raised level of CSF ADA and protein may originate in a local immune response as the result of lymphocytes proliferating in response to the relevant antigen.

In the present series it was observed that in patients having CSF glucose $<40 \mathrm{mg} / \mathrm{dL}$ CSF ADA measured was maximum $(36.03+19.21 \mathrm{U} / \mathrm{L})$ as compared to patients having CSF glucose $>40 \mathrm{mg} / \mathrm{dL}$ (Table No. II). Kennedy et al. reported CSF glucose levels between 30 and $45 \mathrm{mg} / \mathrm{dL}$ in $48 \%$ of the TBM cases in their study. ${ }^{6}$ A highly significant $(\mathrm{P}<0.001)$ negative correlation $(\mathrm{r}=0.58)$ could be established between CSF ADA and CSF glucose in the present study. Similar finding were reported by Malan et al. in 157 cases of TBM $(\mathrm{r}=-0.33, \mathrm{P}<0.001) .{ }^{9}$ Decreased CSF glucose may be due to impairment active transport to increased utilization of glucose by CNS tissue.

Study group 2: Tuberculous pleural effusion Pleural Fluid Biochemistry and Cytology

On pleural fluid examination 25 samples were found clear pale yellow in colour only 5 samples were turbid due to large number of lymphocytes. The total leucocyte count was high
$(724.73+428.94)$ as compared to relatively acellular picture of normal pleural fluid. Lymphocytic predominance $(80.26+27.81)$ was observed. Baganha et al. analyzed seventy three samples of pleural exudates, 25 samples showed $\mathrm{T}$ lymphocyte predominance over B lymphocyte. ${ }^{12}$

Biochemical examination of the pleural fluid revealed exudative nature of the fluid, protein being $>3 \mathrm{gm} / \mathrm{dL}$, glucose content was found low as compared to normal values reported. ADA is considered as a marker of cell mediated immunity. ADA is a polymorphic enzyme involved in purine metabolism, catalyses the deamination of adenosine to inosine and ammonium. Although found in most tissue, ADA activity is greatest in the lymphoid tissue, its activity being 10-20 times more active in $\mathrm{T}$ lymphocytes than in $\mathrm{B}$ lymphocytes.

The determination of ADA activity was first proposed as a serologic diagnostic marker for lung cancer in by Nishihara et al. Later, Piras et al. reported the usefulness of ADA in diagnosing tuberculous pleurisy. ${ }^{10,13}$ Tuberculous pleural effusion is thought to result from a delayed hypersensitivity reaction in response to the presence of mycobacterial antigens in the pleural space. Delayed hypersensitivity reaction causes the stimulation and differentiation of lymphocytes that perform a variety of functions, including the release of certain lymphokines that activate macrophages for enhanced mycobactericidal effect. Because the chief role of ADA concerns the proliferation and differentiation of lymphocytes ADA has been looked on as a marker of cell mediated immunity which encompasses the delayed hypersensitivity reaction.

Previous reports have coated a wide range of cutoff values from $45 \mathrm{U} / \mathrm{L}$ to $80 \mathrm{U} / \mathrm{L}$. In the present study ADA PF cutoff value was $<45 \mathrm{U} / \mathrm{L}$. This difference likely reflects the differences in study population and differing methods of ADA FF analysis therefore when interpreting the results physician should be aware of the different cutoff levels.

In the present series on the basis of pleural fluid ADA estimated study population was classified into two groups having pleural fluid ADA activity $<40 \mathrm{U} / \mathrm{L}$ respectively.

It was observed that in ADA positive samples $(90.78+27.89$ $\mathrm{U} / \mathrm{L})$ the protein content was high $(4.75+1.08 \mathrm{~g} / \mathrm{L})$, glucose content was appreciably low $(47.49+1.08 \mathrm{mg} / \mathrm{L})$ and high leucocyte count $(830.33+390.27)$ as compared to ADA negative samples. The findings correlate with the findings of Riantawan et al. ${ }^{14}$ An attempt was made to correlate ADA level with all these three parameters. Highly significant positive correlation was found between ADA activity and protein content and leucocyte count $(\mathrm{p}<0.001)$. A negative correlation could be established between ADA and pleural fluid glucose levels. 
Ascitic fluid white cell count was $680.46+348.69$ per cumm and consist of lymphocyte predominantly. Martinez Vazuez et al. studied 10 patients of tuberculous peritonitis and reported higher than $70 \%$ of lymphocytes in the samples analysed. ${ }^{15}$

Study group -III Tuberculous ascites

Ascitic fluid biochemistry and cytology :

In the present study peritoneal fluid leucocyte count varied from 96-1430 per cu mm with mean of $680+348.69$. Lymphocytic predominance was observed (78\%) suggesting tuberculous peritonitis. Martinezvazquez et al. studied 10 patients with tuberculous peritonitis confirmed by bacteriologic and histopathologic examinations. ${ }^{15}$ They reported high leucocyte count varying between $472-5840$ per cu mm and lymphocyte percentage between $30 \%-100 \%$.

On biochemical examination protein content was greater than $3 \mathrm{gm} / \mathrm{dL}$ in majority of the patients. The ascitic fluid glucose content was low $(52.62+18.57 \mathrm{mg} / \mathrm{dL})$ as compared to the normal values coated. Hillbrand et al. reported ascitic fluid total protein content $>2.5 \mathrm{~g} / \mathrm{dL}$ in tuberculous peritonitis patients. In recent years, investigators have noted that ADA is markedly raised in tuberculous ascites. ${ }^{17}$

In patients having ADA activity $<40 \mathrm{U} / \mathrm{L}$ the mean ADA was significantly lower as compare to the patients having ADA activity $>40 \mathrm{U} / \mathrm{L}$. On correlating the ADA activity with protein and lymphocyte percentage, highly significant positive correlation was obtained $(\mathrm{p}<0.001)$.

Martinez Vazquez et al. reported no correlation between absolute lymphocyte count and the ADA concertration. ${ }^{15}$ In the present study highly significant negative correlation $(p<0.001)$ was observed between ascitic fluid ADA and glucose content.

The value of ADA estimation for diagnosis of tuberculous meningitis, tuberculous pleural effusion and tuberculous ascites was evaluated in terms of its sensitivity, specificity, positive predictive value (PPV), and Negative predictive value (NPV). The sensitivity and specificity of ADA depends upon the prevalence of tuberculosis in the population. The ADA measurement is used commonly in European and Asian countries where there is a higher incidence of tuberculosis. The problem with using the ADA assay in a population with a lower incidence of tuberculosis is that the positive predictive value decreases; stated another way, there is a higher likelihood that a test would give a false positive result. The downside of this could be unnecessary tuberculosis chemotherapy.

Hence, it is concluded that ADA estimation is a simple cheaper and quicker biochemical test and could provide additional supportive evidence for the diagnosis of tuberculous meningitis, tuberculous pleural effusion, tuberculous ascites in clinically suspected cases and will therefore help in early institution of therapy to these patients.

\section{Conflict of Interest : None}

\section{References:}

1. Piras MA, Gakisc, Braudoni M, Anadreoni G. Adenosine deaminase activity in pleural effusions : An aid to differential diagnosis. Br. Med. J. 1978; 2: 1751-52.

2. Hall JG. Adenosine deaminase activity in lymphoid cells during antibody production. Aust. J. Exp. Bio Med. Sci. 1963; 41: 93-7.

3. Sheth KV. Cerebrospinal and body fluids cell morphology. ASCP workshop manual Chicago American Society of Clincial pathologist. 1977.

4. Kolmel HW. Atlas of cerebrospinal fluid cells. New York, Springer-Verlag, 1977.

5. Cole M. Pit falls in cerebrospinal fluid examination Hosp. Pract. 1969; $4: 47$.

6. Kennedy DH, Fallon RJ . Tuberculous meningitis. JAMA. 1979; 241: 264-268

7. Fishman R.A. cerebrospinal fluid. In Boher,A.B., and Baher L.H. (eds) : Clinical neurology, New York, Harper and Row, Publishers, Inc. 1971.

8. Swartz MN, Dodge PR. Bacterial meningitis - a review of resulted aspects. N. Engl. J. Med. 1965; 272: 275.

9. Malan C, Donald PR, Golden M, Jalgard JJP. Adenosine deaminase level in CSF in the diagnosis of tuberculous meningitis, J. Trop. Med. And Hyg. 1984; 87 : 33.

10. Piras, MA, Gakis, C. Cerebrospinal fluid adenosine deaminase activity in tuberculous meningitis, Enzyme. 1973; 14: 311 .

11. Galanti B, Nardiello S, Russo M, Fiorentino F. Increased lymphocyte adenosine deaminase in typhoid fever. Scand J. infect Disc. 1981; 13: 47-50.

12. Baganha MF, Pego A, Lima MA, Gaspar EV, Cordeiro AR. Serum and pleural adenosine deaminase correlation with lymphocytic population Chest 1990; 97 : 605-10.

13. Nishihara II, Alcodo II, Okado II et al. multiple enzyme pattern of serum adenosine deaminase by Agar gel electrophoresis an evaluation of the diagnostic value in lung cancer. Clin cloarm ACta. 1970; $30: 251-58$.

14. Riantawan P, Chaawalit P, Wongsangiem M., Rojanroweewong P. Diagnostic value of pleural fluid adenosine deaminase in tuberculosis pleuritis with reference to HIV coinfection and a Boyesian Analysis. Chest 1999; $116: 97-103$.

15. Martinez-Vazquez JM, Riberc E, Ocana I, Sengura RM, Serrat R, Sagrista J. Adenosine deaminase activity in tuberculous pericarditis. Thorax. 1986; $41: 888$.

16. Martinez - Vazquez JM, Ocana I, Ribera E, et al. Adenosine deaminase activity in the diagnosis of tuberculous peritonitis. Gut 1986; 27: 1049-53.

17. Hillebrand DJ, Runyon BA, Yasminesh WG, Rynders GP. Ascitic fluid adenosine deaminase insensitivity in detecting tuberculous peritonitis in the United States. Ammerican association for the study of liver diseases. 1996; 24/6 : 1408-1412. 